\title{
PSYCHE
}

VoL. L

MARCH-June, 1943

Nos. 1-2

\section{THE CORPUS ALLATUM OF THE SHEEP KED, MELOPHAGUS OVINUS L.}

\author{
By M. F. Day \\ Washington University, St. Louis, Mo.
}

It has recently been shown (Thomsen, 1941; Day, 1943) that the condition of the corpus allatum and corpus cardiacum in muscoid flies is highly specialized when compared with other insects, since these glands have fused to form the so-called Weismann's Ring or ring gland. Burtt (1937) has found that this condition is not found in the Nematocera which he studied, for a typical paired corpus allatum was present in the larva of species of Chironomus and Tipula. However, Burtt considered the corpus cardiacum to represent the œsophageal ganglion.

In view of the interesting physiological effects of the ring gland on the ovaries reported by Thomsen (1940), the condition of the corpora allata and cardiaca in Melophagus presents a particularly interesting problem, for in this insect viviparity is highly developed. No observations on these glands in Melophagus are to be found in the literature, except those embryological studies of Pratt (1901) referred to below. Other anatomical studies include those of Hoare (1923) and Hardenburg (1929).

The following notes on the corpora allata and cardiaca of Melophagus are presented here as one of a series of investigations of these glands in the Order Diptera. Conclusions regarding the homologies of the structures described are based upon morphological and comparative histological evidence.

The techniques employed have been described previously (Day, 1943). 


\section{Observations on Larvee}

Since almost the entire larval life is spent in the uterus of the female ked, the young larva can be obtained only by dissection or in serial sections of the parent fly. All larval tissues retain many embryonic characteristics. According to Pratt (1901, p. 261) the glands (which he refers to throughout as ganglia allata, following Heymons, 1895) arise from the headfold as a pair of spherical bodies, probably from the lateral ectoderm, rather than from the ventral ectoderm as in most other insects. This is not surprising, however, in view of the great modification in the development of other organs of these Diptera when compared with more generalized insects.

The number of larval instars has not been determined. Larvæ are therefore classified according to their size. Three stages are described in detail. The youngest larva studied in the present series was about $0.8 \mathrm{~mm}$. in length. This stage is only slightly more advanced than Pratt's (1901) Figs. 43 and 44 , and already the tissue forming the corpora allata can be clearly distinguished from the brain tissue. The unusually large size of the cells is clearly seen in Pratt's illustrations. Cytologically the corpus allatum cells are very characteristic, presenting a considerably larger amount of even, deeply staining, basophilic cytoplasm than is found in any other cells of the embryo.

In a larva approximately $2 \mathrm{~mm}$. in length (Fig. 1) the gland has increased in cell size and in cell number, but not to such an extent that each cell could have divided once. The cytoplasm is even more basophilic than that of the younger larva, and the cells appear to be in a state of secretory activity. In five mature larvæ studied corpora allata are greatly enlarged (Fig. 2). It is to be noted that the gland is a paired structure and thus differs fundamentally from the median corpus allatum of the Brachycera. Moreover, the cells composing it are large and conspicuous and show cytological indications of considerable activity, while the corpus allatum in the larva of Brachycera shows no cytological evidence of secretory changes. The corpus cardiacum, however, is inconspicuous in the larva of Melophagus, again in striking contrast to the situation in the Brachycera.

Each corpus allatum of a mature larva measures approximately 150 microns x 125 microns, and extends from the median region laterally between the imaginal discs and the dorsal ex- 
tension of the developing gut. The cells comprising the gland have distinct cell boundaries and show no indications of forming a syncytium. While there is some variability in nuclear size, there does not appear to be any differentiation into more than one cell type. Measurements of the diameters of 100 nuclei from both glands of a single larva, representing approximately one fifth of the total nuclei, give a unimodal distribution curve with a range of 8.5 to 13.0 microns and a mean of 11.0 microns. Nucleoli are conspicuous and the chromatin evenly distributed following the fixatives employed. The cytoplasm in the cells at this stage exhibits conspicuous vacuoles which are generally peripherally located. There are usually one or two large vacuoles and a number of smaller ones, which give the cytoplasm the appearance of a reticulum, especially after Bodian's technique. As compared with the young larva, the cells representing the corpus cardiacum have been greatly reduced. From cytological evidence it would appear that their principal activity occurs during larval development.

The Pupa. It would be desirable to have a closely spaced series of pupæ, for during this time very active changes occur in the cells of the corpora allata. Unfortunately only a few pupæ ( 3 "white" pupæ, 1 of about two weeks of age and 2 nearly mature pupæ) were available, but these all agree in showing a marked reduction in the size of the corpora allata. Not only does the cytoplasm become reduced, but nuclear size also decreases. This decrease amounts to about 25 per cent of the former volume. Rhythmic increase in nuclear size is a not uncommon phenomenon in insect tissues (see Geitler, 1940, for review), but a striking decrease as found here is unusual. Moreover, there is a decrease in number of cells, a change reminiscent of that undergone by the mammalian thymus during development, and, as in the thymus, the mechanism of the reduction of the cell number has not been determined.

Pupal development of Melophagus occupies approximately three weeks. The puparium is white in color immediately after formation, but it hardens and darkens within about four hours. The corpus allatum of the white pupa is not unlike that of the fully grown larva. Considerable vacuolization of the cytoplasm is evident; the cells are approximately 15 microns in diameter and the nuclei average about 8.7 microns. As development proceeds, the cells lose more and more cytoplasm until, by the end 
of pupal development, they have assumed the form found in the adult. The glands have moved posteriorly, and come to lie, as they do in all adult Diptera, immediately in front of the proventriculus.

The Adult. No differences have been found in the corpora allata of male (Fig. 3) and female (Fig. 4) Melophagus, nor in female Melophagus with or without larvæ. The glands are ovoid, measuring approximately 75 microns x 60 microns. Each contains approximately twenty cells in cross section in the region of greatest diameter, the cells having approximate dimensions of 12 microns $\times 13$ microns. The two glands lie one on each side of the dorsal aorta (Figs. 5 and 6). Ventral to them are the convolutions of the salivary glands, and immediately above them there are conspicuous tracheal trunks, which arise from the mesothoracic spiracles. Immediately above the aorta there are numbers of large pericardial cells which are frequently multinucleate, and possess a coarsely reticulated cytoplasm.

The cytoplasm of the cells of the corpora allata is sparse in comparison with that of the previous stages, and contains few or no vacuoles. The diameter of the nuclei is approximately 7.3 microns. Their volume is thus approximately 25 per cent that of the nuclei of the mature larvæ. The single large nucleoli are almost always eccentric. The cells are well innervated by nerve fibers arising from the region of the corpus cardiacum. Almost all traces of the secretory elements of the last mentioned gland have disappeared, but there remain a number of nerve cell bodies representing the hypocerebral ganglion. These are loosely arranged, and do not form a compact gland-like structure as is found in Lucilia. A second cell type represented by small cells scattered among the nerve cell bodies is probably connective tissue and supporting cells. The gross arrangement of the incretory organs is most clearly seen in Fig. 6.

The most striking point of the observations reported above is the fact that the changes undergone by the corpora allata of Melophagus are so different from those occurring in Lucilia sericata as described by Day (1943). Whereas in the latter, the corpus allatum is very inconspicuous in the larva, and its cells reproduce by mitosis during the pupal period, in Melophagus the corpora allata reach their maximum size during late larval development, and are considerably reduced in both 
pupa and adult. Cytologically the cells of the adult Melophagus behave similarly to those of Lucilia. Neither show visible evidence of secretory activity, though in Lucilia, at least, marked physiological effects of the ring gland have been demonstrated by experiments.

The changes undergone by the cells of the corpora allata which have been described above can be tabulated as follows:

TABLE 1

Changes in the Cells of the corpora allata of Melophagus during DEVELOPMENT

\begin{tabular}{|c|c|c|c|}
\hline \multirow[b]{2}{*}{ Stage } & \multirow{2}{*}{$\begin{array}{l}\text { Approximate number } \\
\text { of cells in each } \\
\text { corpus allatum }\end{array}$} & \multicolumn{2}{|c|}{ Average size in microns } \\
\hline & & Nucleus & Cell \\
\hline $2 \mathrm{~mm}$. larva & 250 & 6.9 & $11 \times 15$ \\
\hline mature larva & 300 & 11.0 & $17 \times 19$ \\
\hline white pupa. & $\ldots$ & 8.7 & $14 \times 15$ \\
\hline adult $\ldots \ldots$ & 100 & 7.3 & $12.5 \times 13$ \\
\hline
\end{tabular}

The reduction in the corpus cardiacum during late larval and pupal development in Melophagus is in general similar to the reduction found in Lucilia, but this gland is never very conspicuous in Melophagus and practically absent in the adult.

It is perhaps not surprising to find such differences in the behavior of the incretory organs of Melophagus and Lucilia when one considers the great differences in their reproductive processes, but the fact that the corpus allatum is a single median organ in Lucilia and paired in Melophagus, as in Nematocera and the majority of insects, is evidence that there are some fundamental differences between the Hippoboscoidea and Muscoidea.

\section{Summary ANd Conclusions}

The incretory organs associated with the stomodeal nervous system of Melophagus exhibit the following characteristics:

1. There is a pair of corpora allata, as in Nematocera and the majority of other insects, rather than a median unpaired structure as in the higher Diptera. The cells and nuclei are extremely large in the larva, and so differ in this also from those of the corpora allata of the Brachycera. 
2. The cells of the corpora allata exhibit cytological evidence of secretory activity in the young larva - thus differing fundamentally from the corpus allatum component of the ring gland of the Brachycera which have been studied.

3 . The vacuolization of the cytoplasm of the corpus allatum cells at the time of puparium formation and pupation is comparable to that found in the corpora cardiaca of Brachycera, and suggests that the gland is physiologically active at this time.

4. The reduction in cytoplasm of the cells of the corpus allatum in the adult as compared with the larva is a further unique feature of Melophagus.

5. The corpus cardiacum is a single median organ, not well developed in the larva of Melophagus, decreasing in the pupa and practically absent in the adult. While the reduction during development is characteristic of Brachycera, the extreme reduction is unique among those insects which have been studied.

The many unusual characters enumerated above correlate with the unusual reproductive habits of Melophagus, but it would be of little value to suggest the functional significance of the observations until some experimental procedures have been applied to this most interesting insect. The difficulties of breeding this species under controlled conditions in the laboratory has so far made such work impractical.

BIBLIOGRAPHY

Burtt, R. T.

1937. On the Corpora Allata of Dipterous Insects. Proc. Roy. Soc. B., 124:13-22.

Day, M. F.

1943. The Homologies of the Ring gland of Diptera Brachycera. Ann. Ent. Soc. Amer., 36:1-10.

Geitler, L.

1940. Neue Untersuchungen über Bau und Wachstum des Zellkerns in Geweben. Naturwiss., 28:247-248.

Hardenburg, J. D.

1929. Beiträge zur Kenntnis der Pupiparen. Zool. Jarb. Anat., 50:497-570.

Heymons, R.

1895. Die Embryonalentwicklung von Dermapteren und Orthopteren. 136 pp. Jena.

Hoare, C. A.

1923. An Experimental Study of the Sheep Trypanosome and its Transmission by the Sheep Ked, Melophagus ovinus L. Parasit., 15:365-424. 
Pratt, H. S.

1901. The Embryonic History of Imaginal Discs in Melophagus ovinus L., together with an account of the Earlier Stages in the Development of the Insect. Proc. Boston Soc. Nat. Hist., 24:241-272.

Thomsen, E.

1940. Relation between Corpus allatum and Ovaries in Adult Flies (Muscidae). Nature, 145:28.

-1941. Ringdrüse und Corpus allatum bei Musciden. Naturwiss., 40:605-606.

\section{Description of Plate I}

The corpora allata of Melophagus ovinus L. Figs. 1-4 from transverse serial sections, 10 microns in thickness, Bodian silver impregnation. Drawn with camera lucida with $10 \mathrm{x}$ ocular and $44 \mathrm{x}$ objective, magnification 200 diameters. Figs. 5-6 drawn from dissections of flies fixed by injection with alcoholic Bouin.

Fig. 1. T. S. $2 \mathrm{~mm}$. larva, showing relationships of corpora allata, corpus cardiacum tissue and other tissues of the larval head. Note the large size of the cells of the corpora allata.

FIG. 2. T. S. portion of a mature larva showing huge increase in size of corpora allata mainly brought about by increase in cell size, which is accompanied by an increase in nuclear size.

Figs. 3 and 4. T. S. head adult male and female Melophagus showing the paired corpora allata and their relation to other organs.

Figs. 5 and 6. Dorsal and lateral aspects of proventriculus, aorta and suboesophageal ganglion, showing the location and anatomical relationships of the corpora allata.

Key to Abbreviations

$\begin{array}{llll}\text { AO. } & \text { Aorta } & \text { N.C.A. } & \text { Nerve to corpora allata } \\ \text { C.A. } & \text { Corpora allata } & \text { OES. } & \text { CEsophagus } \\ \text { C. C. } & \text { Corpora cardiaca } & \text { P.N. } & \text { Pericardial nephrocytes } \\ \text { C. GAN. } & \text { Cerebral ganglion } & \text { PROV. } & \text { Proventriculus } \\ \text { D.C. } & \text { Duct to crop } & \text { SAL. GL. } & \text { Salivary glands } \\ \text { FT. BDY. } & \text { Fat body } & \text { TH. GAN. } & \text { Thoracic ganglion } \\ \text { HYP. GAN. Hypocerebral ganglion } & \text { TR. } & \text { Trachea } \\ \text { M.G. } & \text { Midgut } & \text { V.N.C. } & \text { Ventral nerve cord } \\ \text { MUS. } & \text { Muscle fibers. } & & \end{array}$




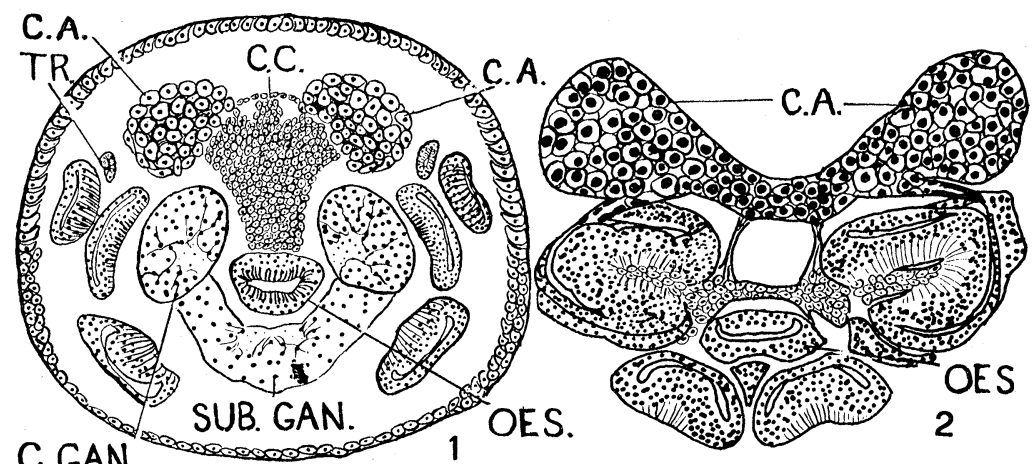

C. GAN.

P.N.

C.A. HYP. GAN.

P.N.

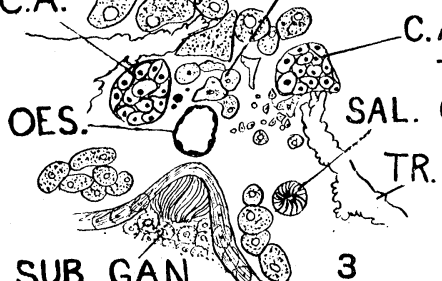

SUB. GAN. 3

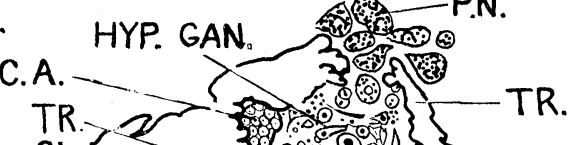

N.C.A.

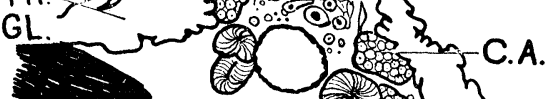

C.A.

FT. BDY.
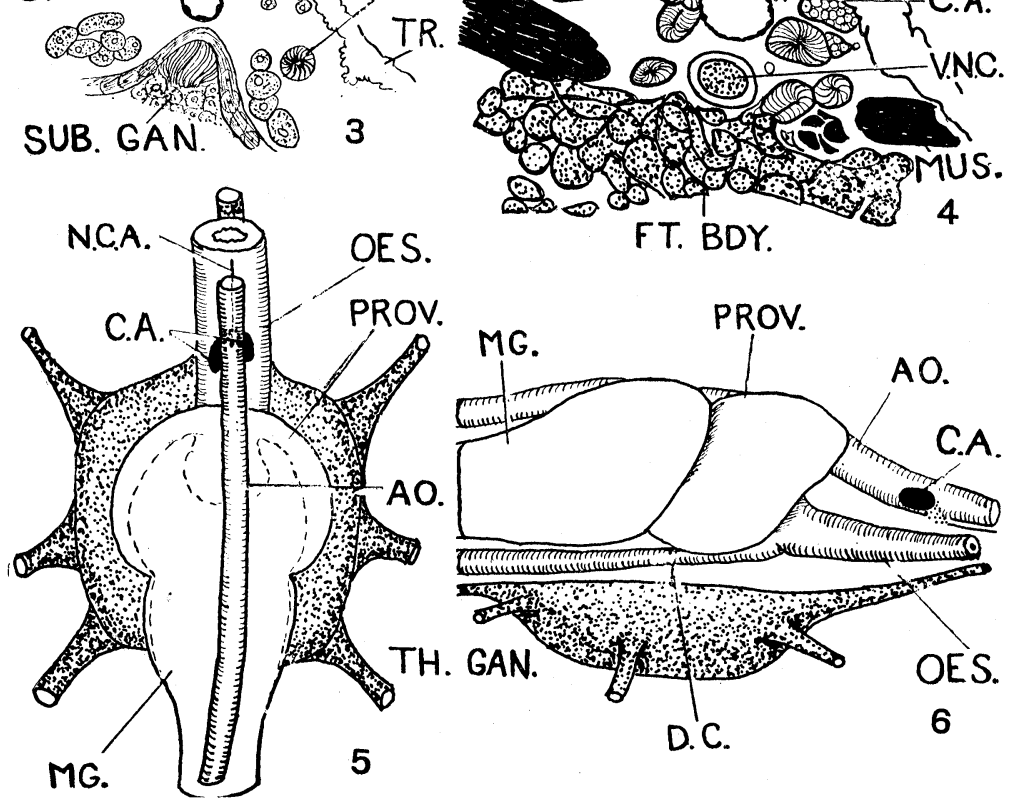

Day - Corpus allatum 

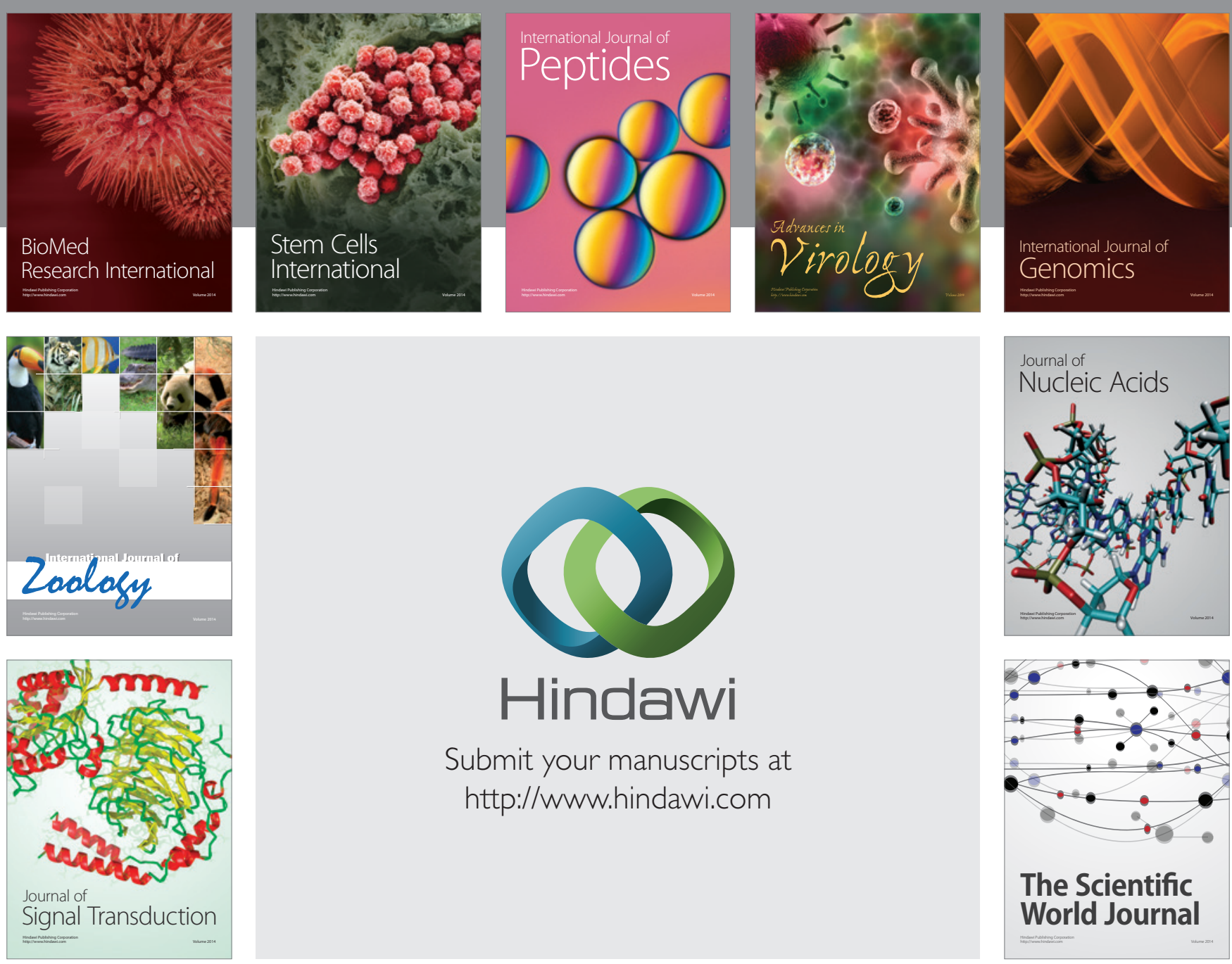

Submit your manuscripts at

http://www.hindawi.com
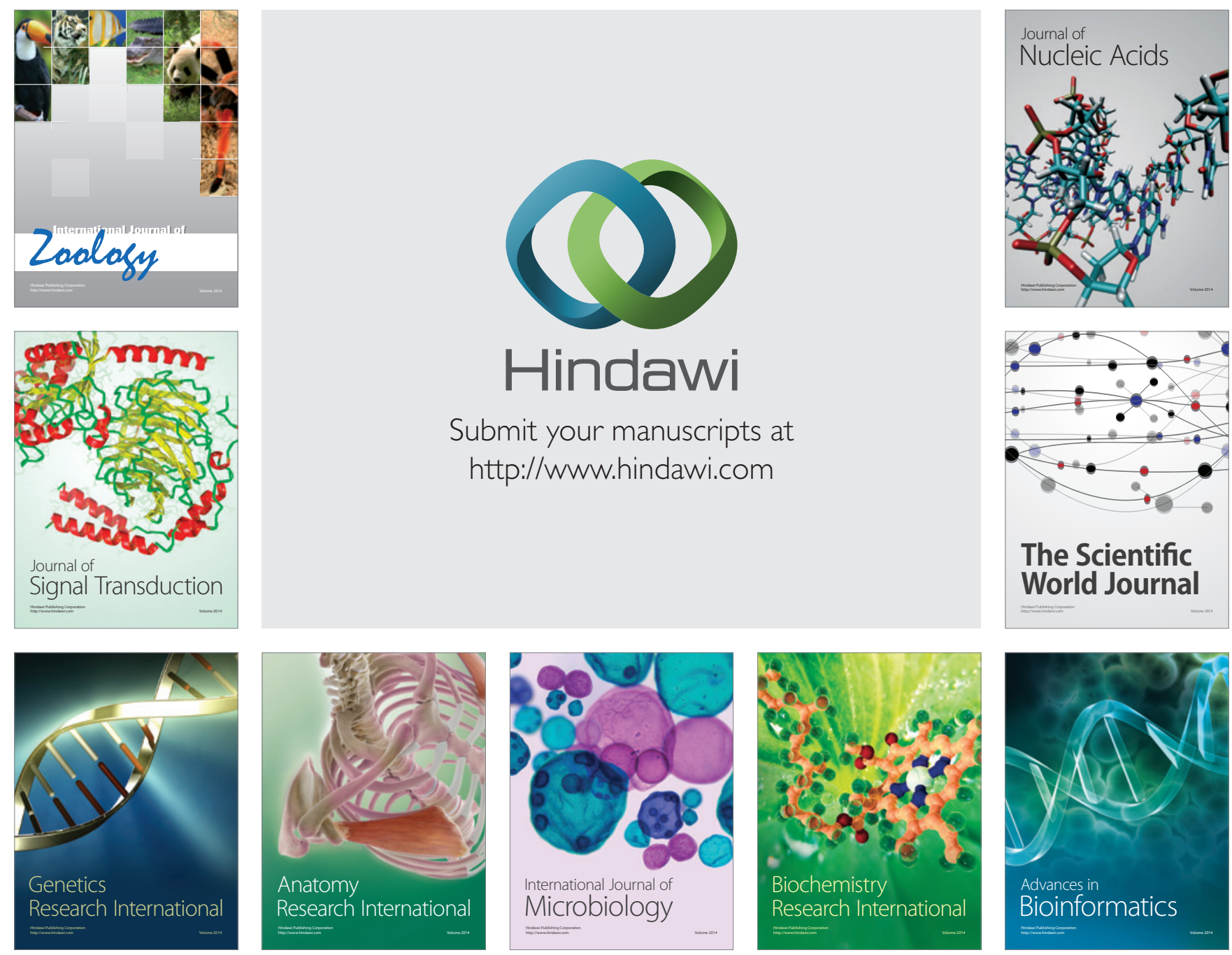

The Scientific World Journal
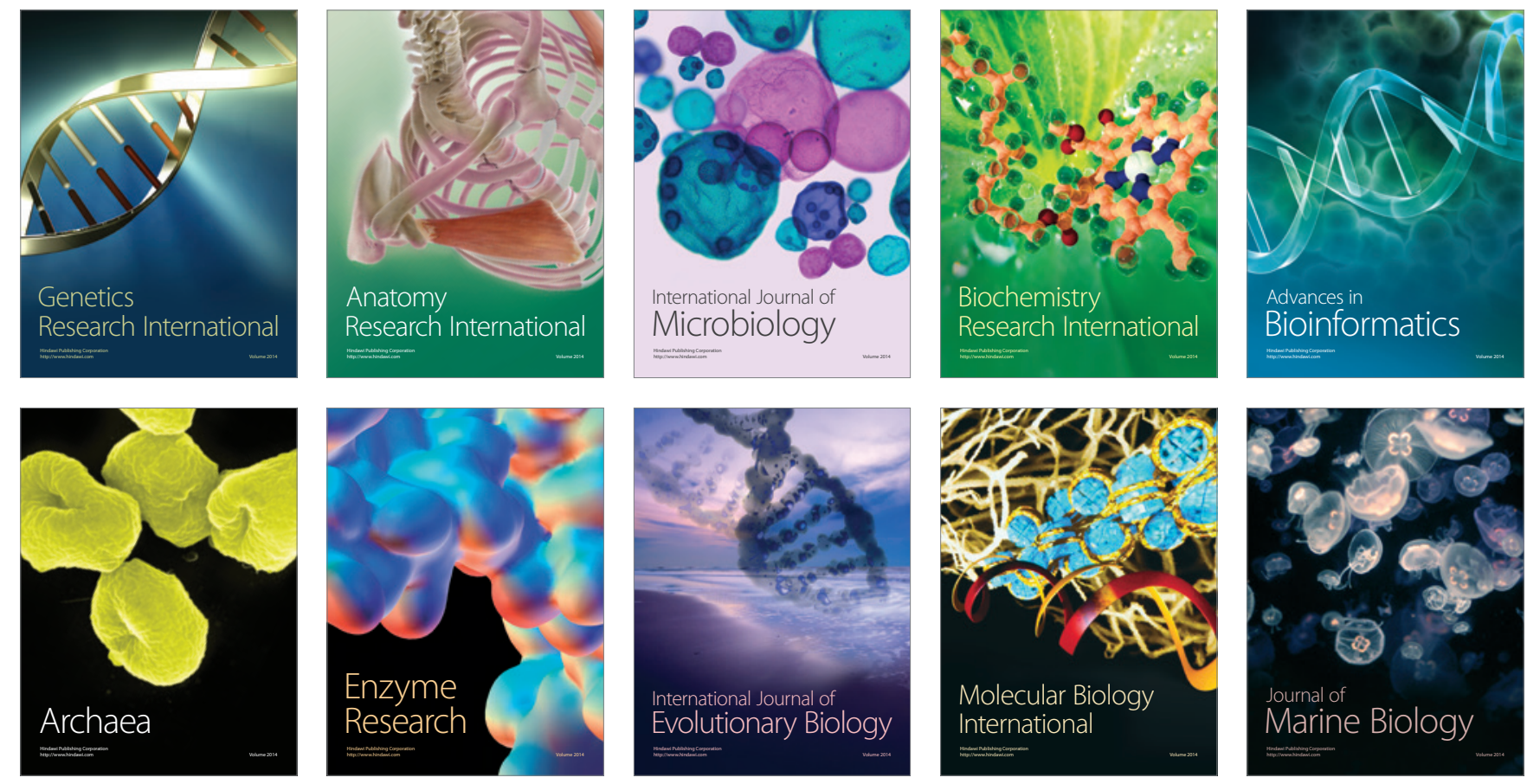